\title{
ANALISIS PENGARUH CURRENT RATIO, DEBT TO EQUITY RATIO, DAM RETURN ON EQUITY TERHADAP RETURN SAHAM PADA PERUSAHAAN REAL ESTATE DAN PROPERTY YANG TERDAFTAR DIBURSA EFEK INDONESIA PERIODE 2014-2017
}

\author{
Wahyu Ridha Latifah \\ wahyuridha73@gmail.com \\ Universitas Ahmad Dahlan \\ Permata Dian Pratiwi \\ permata.pratiwi@mgm.uad.ac.id \\ Universitas Ahmad Dahlan
}

\begin{abstract}
ABSTRAK
This research was conducted with the aim to empirically examine the effect of Current Ratio, Debt to Equity Ratio and Return on Equity Against Stock Returns on Real Estate and Property Companies on the Indonesia Stock Exchange. The research period was carried out for 4 (four) years, namely 2014-2017. This type of research is causal research, that is, this study looks for a causal relationship between independent variables and the dependent variable. The population in this study are all Real Estate and Property companies listed on the IDX, wich were 48 Real Estate and Property. The sample in this study was obtained by purposive sampling method that is sampling based on criteria; (1) Registered as an active Real Estate and Property company on the Indonesia Stock Exchange (IDX) in 20142017, (2) Companies that publish their annual reports on the IDX, (3) Real Estate and Property Companies that issue CR, DER and ROE for each consecutive period from 20142017. Based on these criteria, 36 Real Estate and Property companies were obtained. Hypothesis testing is done by panel data regression analysis, but before testing hypotheses first testing classicalassumptions. The results of hypothesis testing are done partially, namely the $t$ test shows that $\mathrm{CR}$ has a positive and insignificant effect on stock returns, DER has a significant negative effect on stock returns and ROE has a significant positive effect on stock returns.
\end{abstract}

Keywords: Current Ratio, Debt to Equity Ratio, Return On Equity, Stock Return.

\begin{tabular}{l}
\hline \multicolumn{3}{c}{ PENDAHULUAN } \\
\\
Perkembangan \\
yang ada di Indonesia secara tidak \\
langsung menuntut para pelaku usaha \\
untuk berkembang dan bertahan disektor \\
industrinya. Pesatnya perkembangan pasar \\
modal di Indonesia telah menjadi suatu \\
lembaga investasi yang berperan penting \\
dalam meningkatkan pertumbuhan \\
ekonomi, dan banyak pula para investor \\
yang melakukan investasi dalam dunia
\end{tabular}

saham. Tujuan para investor berinvestasi saham yaitu memperoleh keuntungan, selain itu juga memperoleh return atau imbal hasil yang nantinya dapat menjamin hidup mereka di masa datang. Motivasi mendapatkan return membuat para investor semakin tertarik untuk berinvestasi di pasar saham. Return saham adalah tingkat pengembalian saham atas investasi yang dilakukan oleh investor (Hartono, 2010). 
Perkembangan pasar modal di Indonesia sudah semakin pesat. Hal tersebut dibuktikan dengan semakin banyaknya perusahaan yang terdaftar di Bursa Efek Indonesia. Perkembangan tersebut di dorong oleh berbagai upaya penyempurnaan dan perbaikan yang dilakukan secara terus - menerus pada pasar modal Indonesia. Salah satu industri yang banyak dilirik oleh investor adalah industri real estate dan property. Definisi real estate yaitu merupakan tanah yang ditambah secara permanen, termasuk bangunan, gudang dan barangbarang lain yang melekat pada struktur. Contohnya: rumah, gedung, perkantoran, pabrik-pabrik, gedung toko ritel. Definisi property adalah setiap kepemilikan yang terpasang langsung ke tanah, serta tanah itu sendiri. Property tidak hanya mencakup bangunan dan struktur lainnya tetapi juga hak - hak dan kepentingan (www.sahamok.com).

Sektor property dinilai memiliki peranan penting dalam menyumbang pertumbuhan perekonomian nasional. Ketua umum DPP Real Estate Indonesia (REI), Soelaeman Soemawinata mengungkapkan hal tersebut saat penandatanganan kerjasama antara Bank Indonesia dan REI dalam penyediaan data property yang akurat di Jakarta, pada tahun 2017 lalu nilai kapitalisasi 35\% saham dari 46 grup property yang tercatat di Bursa Efek Indonesia mencapai 280 triliun (www.kompas.com).

Pertumbuhan jumlah penduduk yang meningkat menyebabkan kebutuhan akan tempat tinggal, perkantoran, pusat perbelanjaan, taman hiburan, dan kebutuhan pada real estate dan property juga mengalami kenaikan sehingga menjadikan real estate dan property tumbuh dengan pesat. Pertumbuhan ini tentu saja akan menarik minat para investor dikarenakan harga tanah dan bangunan yang cenderung terus naik, penawaran tanah bersifat tetap sedangkan permintaan selalu bertambah besar seiring dengan pertambahan jumlah penduduk serta bertambahnya kebutuhan manusia setiap tahunnya.

Para investor menyadari akan hal yang terjadi di Indonesia sehingga tidak sedikit investor menginvestasikan saham mereka ke sektor property. Investor menginvestasikan saham mereka dengan tujuan untuk medapatkan keuntungan (capital gain) pada saat saham mereka di jual kembali dan memaksimalkan return dengan tidak mengabaikan risiko yang akan dihadapinya. Investor harus melakukan penilaian harga saham terlebih dahulu agar dapat memperoleh tingkat pengambalian saham (return) dan keuntungan yang sesuai dengan yang diharapkan. Salah satu informasi yang dapat dipakai oleh investor sebagai bahan pertimbangan dan pengambilan keputusan investasinya adalah melalui analisis rasio keuangan. Rasio keuangan merupakan angka yang diperoleh dari hasil perbandingan dari satu akun laporan keuangan dengan akun lainnya yang mempunyai hubungan yang relevan dan signifikan (Harahap, 2009).

Penilaian ini menggunakan indikator return saham untuk menilai saham pada perusahaan real estate dan property di Bursa Efek Indonesia. Return saham juga menunjukkan nilai suatu perusahaan. Nilai saham merupakan indeks yang tepat untuk efektifitas perusahaan. Semakin tinggi return saham , maka semakin tinggi pula nilai perusahaan tersebut dan sebaliknya. Setiap perusahaan yang menerbitkan saham sangat memperhatikan return sahamnya. Harga yang terlalu rendah sering diartikan bahwa kinerja perusahaan kurang baik. Namun bila return saham terlalu tinggi mengurangi kemampuan 
investor untuk membeli sehingga menimbulkan return saham sulit untuk meningkat lagi.

Dalam penelitian ini, peneliti menggunakan rasio likuiditas yang diproksikan dengan menggunakan current ratio, leverage yang diproksikan menggunakan Debt to Equity Ratio, dan profitabilitas yang diprosikan menggunakan Return On Equity. Analisis likuiditas (Munawir, 2014) adalah analisis yang paling umum digunakan untuk menganalisis dan menginterpretasikan posisi keuangan jangka pendek. Apabila perusahaan dapat memenuhi kewajiban dalam jangka pendek maka perusahaan tersebut dinyatakan dalam kondisi likuid. Rasio likuiditas diukur dengan current ratio $(\mathrm{CR})$ yang membandingkan antara aktiva lancar dan hutang lancar suatu perusahaan (Hanafi dan Halim, 2012).

Current ratio yang rendah menunjukkan risiko likuiditas yang tinggi menyebabkan perusahaan dalam kondisi illikuid dan penurunan tingkat profitabilitas. Sedangkan current ratio yang tinggi menunjukan adanya kelebihan aktiva lancar yang membawa pengaruh kurang baik pada return saham. Namun, current ratio yang tinggi tidak sepenuhnya berpengaruh buruk terhadap return saham. Artinya, current ratio yang tinggi tidak menutup kemungkinan perusahaan menghasilkan return saham yang tinggi.

Rasio leverage merupakan rasio yang digunakan untuk mengukur sejauh mana aktiva perusahaan dibiayai dengan utang. Artinya, berapa besar beban utang yang ditanggung perusahaan dibandingkan dengan aktivanya. Dalam arti luas dikatakan bahwa rasio leverage digunakan untuk mengukur kemampuan perusahaan untuk membayar seluruh kewajibannya baik jangka pendek maupun jangka panjang apabila perusahaan dibubarkan atau dilikuidasi (Kasmir, 2015). Analisis leverage diukur dengan debt to equity ratio (DER) yang dapat dihitung dengan membandingkan total hutang dan total aset suatu perusahaan. Perusahaan yang memiliki kinerja bagus biasanya memiliki nilai hutang yang lebih rendah. Semakin besar hutang perusahaan semakin kecil laba yang diterima perusahaan. Apabila laba perusahaan kecil maka return saham yang dihasilkan rendah.

Menurut Kasmir (2015) rasio profitabilitas merupakan rasio untuk menilai kemampuan perusahaan dalam mencari keuntungan. Rasio ini juga memberikan ukuran tingkat efektivitas manajemen suatu perusahaan. Hal ini ditunjukkan oleh laba yang dihasilkan dari penjualan dan pendapatan investasi. Intinya bahwa penggunaan rasio ini menunjukkan efisiensi perusahaan. Disini rasio profitabilitas diproksikan dengan Return On Equity.

ROE merupakan ukuran kemampuan perusahaan dalam menghasilkan keuntungan dengan menggunakan modal sendiri, sehingga ROE ini sering disebut sebagai rentabilitas modal sendiri. Jika perusahaan dapat menghasilkan laba yang tinggi, maka permintaan saham akan meningkat dan selanjutnya akan berdampak pada meningkatnya harga saham perusahaan. Ketika harga saham semakin meningkat maka return saham juga akan meningkat. Di sisi lain tingkat ROE yang tinggi akan berdampak pada rendahnya tingkat penggunaan dana eksternal. Hal ini disebabkan perusahaan yang memiliki profitabilitas yang tinggi akan mempunyai dana internal yang besar, sehingga ROE berpengaruh positif terhadap return saham.

Tujuan dari penelitian ini adalah: 1) untuk mengetahui pengaruh Current Ratio terhadap return saham, 2) untuk 
mengetahui pengaruh Debt to Equity Ratio terhadap return saham dan 3) untuk mengetahui pengaruh Return on Equity terhadap return saham.

\section{REVIEW LITERATUR DAN HIPOTESIS}

\section{Landasan Teori}

\section{Analisis Kinerja Keuangan}

Analisis kinerja keuangan perusahaan salah satunya dapat diukur dengan rasio keuangan. Menurut Harahap (2009), rasio keuangan merupakan angka yang diperoleh dari hasil perbandingan dari satu akun laporan keuangan dengan akun lainnya yang mempunyai hubungan yang relevan dan signifikan. Menurut Hanafi (2009), rasio keuangan dapat dikelompokkan ke dalam lima macam kategori yaitu:

a. Rasio Likuiditas, yaitu rasio yang mengukur kemampuan perusahaan memenuhi kewajiban jangka pendeknya.

b. Rasio Aktivitas, yaitu rasio yang mengukur sejauh mana efektivitas penggunaan aset dengan melihat tingkat aktivitas aset.

c. Rasio Solvabilitas, yaitu rasio yang mengukur sejauh mana kemampuan perusahaan memenuhi kewajiban jangka panjangnya.

d. Rasio Profitabilitas, yaitu rasio yang melihat kemampuan perusahaan menghasilkan laba.

e. Rasio Pasar, yaitu rasio ini melihat perkembangan nilai perusahaan relatif

terhadap nilai buku perusahaan.

Dalam penelitian ini penulis hanya mengambil beberapa rasio keuangan yang berkaitan dengan rumusan masalah di antaranya adalah rasio likuiditas yang diproksikan dengan Current Ratio, rasio solvabilitas yang diproksikan dengan Debt to Equity Ratio dan rasio profitabilitas yang diproksikan dengan Return On Equity.

\section{Return Saham}

Menurut Tandelilin (2010), return saham merupakan salah satu faktor yang memotivasi investor berinvestasi dan juga merupakan imbalan atas keberanian investor menanggung resiko atas berinvestasi yang dilakukannya. Return merupakan hasil yang diperoleh dari suatu investasi dari dana yang sudah diinvestasikan yang dapat dinikmati oleh investor. Investor harus benarbenar menyadari bahwa disamping akan memperoleh keuntungan tidak menutup kemungkinan mereka akan mengalami kerugian. Keuntungan atau kerugian yang dialami investor sangat dipengaruhi oleh kemampuan seorang investor dalam menganalisis keadaan harga saham.

Return dapat berupa return realisasi yaitu return yang telah terjadi, dihitung berdasarkan data historis dan digunakan untuk mengukur kinerja perusahaan (Hartono, 2007). Menurut Hartono (2008), Return realisasi (realized return) merupakan return yang telah terjadi. Return realisasi dihitung berdasarkan data historis. Realisasi penting karena digunakan sebagai salah satu pengukur kinerja dari perusahaan. Return historis ini juga berguna sebagai dasar penentu return ekspektasi (expected return) dan risiko dimasa datang.

Menurut Halim (2005), return saham terdiri dari dua komponen utama, yaitu:

a. Gain, yaitu merupakan keuntungan bagi investor yang diperoleh dari kelebihan harga jual di atas harga 
beli yang keduanya terjadi di pasar sekunder.

b. Yield, merupakan pendapatan atau aliran kas yang diterima secara periodik, misalnya berupa deviden atau bunga.

\section{Penelitian Terdahulu}

Ratna (2009) dalam penelitiannya mengenai "Analisis Pengaruh Rasio Likuiditas, Aktivitas, Leverage dan Profitabilitas Terhadap Return Saham Pada Perusahaan Manufaktur yang Terdaftar di BEI Periode Tahun 20052007", menyimpulkan bahwa CR berpengaruh positif terhadap return saham, TATO tidak berpengaruh terhadap return saham, DER tidak berpengaruh negatif terhadap return saham, ROI tidak berpengaruh positif terhadap return saham.

Prihantini (2009) dalam penelitiannya mengenai "Pengaruh Inflasi, Nilai Tukar, ROA, DER dan CR terhadap Return Saham industry real estate and property yang listed di Bursa Efek Indonesia periode 2003-2006", menyimpulkan bahwa Inflasi berpengaruh negatif dan signifikan terhadap return saham, CR berpengaruh positif dan signifikan terhadap return saham, Nilai tukar berpengaruh negatif dan signifikan terhadap return saham, ROA berpengaruh positif dan signifikan terhadap return saham, DER berpengaruh negatif dan signifikan terhadap return saham.

Kurnia (2013) dalam penelitiannya mengenai" Pengaruh Kinerja Perusahaan Dan Risiko Sistematis Terhadap Return Saham (Studi Empiris pada Perusahaan Property dan Real Estate yang Terdaftar di BEI)", menyimpulkan bahwa EPS berpengaruh signifikan positif terhadap return saham, DER tidak berpengaruh signifikan terhadap return saham, Risiko sistematis berpengaruh signifikan positif terhadap return saham.

Yunita (2013) dalam penelitiannya mengenai "Analisis Pengaruh Rasio Profitabilitas Dan Rasio Solvabilitas Terhadap Return Saham Perusahaan
Manufaktur Yang Terdaftar Di BEI Periode 2008-2010", menyimpulkan bahwa Variabel EPS dan ROE terbukti berpengaruh positif dan signifikan terhadap return saham, variabel NPM, ROA dan DER tidak berpengaruh terhadap return saham, Variabel EPS, NPM, ROA, ROE dan DER secara bersama-sama mempunyai pengaruh yang signifikan terhadap return saham.

Verawati (2014) dalam penelitiannya mengenai "Faktor-Faktor Penentu Yang Mempengaruhi Return Saham Perusahaan Manufaktur Yang Terdaftar Di Bursa Efek Indonesia (BEI) Periode 2008-2013", menyimpulkan bahwa EPS, PBV terdapat pengaruh positif dan signifikan terhadap return saham, PER tidak terdapat pengaruh positif dan signifikan terhadap return saham, DER terdapat pengaruh negatif dan signifikan terhadap return saham. Terdapat pengaruh yang signifikan variabel EPS, PER, DER dan PBV secara bersama-sama (simultan) terhadap Return Saham.

Laksono (2017) dalam penelitiannya mengenai "Pengaruh Rasio Keuangan Terhadap Return Saham Pada Perusahaan Manufaktur Yang Terdaftar Di Bursa Efek Indonesia", menyimpulkan bahwa Current Ratio berpengaruh positif terhadap return saham, Debt to Equity Ratio berpengaruh negatif terhadap return saham, Return on Asset tidak berpengaruh terhadap return saham, Total Assets Turnover berpengaruh positif terhadap return saham, Price to Book Value tidak berpengaruh terhadap return saham.

\section{Hipotesis}

H1: Current Ratio berpengaruh positif dan signifikan terhadap return saham.

H2: Debt to Equity Ratio berpengaruh negatif dan signifikan terhadap return saham.

H3: Return On Equity berpengaruh positif dan signifikan terhadap return saham. 


\section{METODE PENELITIAN}

\section{Populasi dan Sampel}

Populasi adalah wilayah generalisasi yang terdiri dari atas objek/subyek yang mempunyai kualitas dan karakteristik tertentu yang ditetapkan oleh peneliti untuk dipelajari kemudian ditarik kesimpulannya (Sugiyono, 2012). Populasi perusahaan Real Estate dan Property yang terdaftar di Bursa Efek Indonesia tahun 2014-2017 berjumlah 48 perusahaan.

Sampel yang digunakan dalam penelitian ini sebanyak 36 perusahaan. Pengambilan sampel dalam penelitian ini dilakukan dengan menggunakanteknik purposive sampling yaitu pengambilan sampel berdasarkan kriteria tertentu:

a. Terdaftar sebagai perusahaan Real Estate dan Property aktif yang ada di Bursa Efek Indonesia (BEI) pada tahun 2014-2017.

b. Perusahaan yang mempublikasikan laporan tahunannya di BEI.

c. Perusahaan Real Estate dan Property yang menerbitkan CR, DER dan ROE tiap periode berturut-turut mulai tahun 2014-2017.

\section{Teknik Pengumpulan Data}

Data dalam penelitian inio diambil dari laporan keuangan yang diterbitkan di Bursa Efek Indonesia. Metode pengumpulan data menggunakan metode dokumentasi, yaitu suatu metode pengumpulan data yang memperoleh sumbe data dari media elektronik, prospektus perusahaan, sampai internet.

Dalam hal ini, data laporan keuangan Real Estate dan Property diperoleh dari laporan keuangan yang dapat diakses melalui www.idx.co.id, yaitu untuk mencari data variabel dependen dan independen. Sedangkan untuk mencari data laporan keuangan untuk perhitungan pada variabel independen yaitu return saham pada tahun 2013 melalui www.yahoofinance.com. Penelitian ini menggunakan periode penelitian dari tahun 2014-2017.

\section{Definisi Operasional}

1. Variabel Dependen

a. Return Saham

Variabel dependen dalam penelitian ini adalah return saham. Return saham yang digunakan dalam penelitian ini yaitu return saham pada harga penutupan (closing price) tiap akhir tahun 2014-2017. Return saham dapat dirumuskan sebagai berikut:

Rit $=\left(\mathrm{Pi}_{\mathrm{t}}-\mathrm{Pi}_{\mathrm{t}-1}\right) /\left(\mathrm{Pi}_{\mathrm{t}-1}\right)$

Rit $=$ perusahaan $\mathrm{i}$ pada periode $\mathrm{t}$

Pit = Harga saham perusahaan $\mathrm{i}$ periode $\mathrm{t}$

$\mathrm{Pi}_{\mathrm{t}-1}=$ Harga saham perusahaan $\mathrm{i}$ periode $_{t-1}$

2. Variabel Independen

\section{a. Current Ratio}

Current Ratio Menurut Kasmir (2015), merupakan rasio untuk mengukur kemampuan perusahaan dalam membayar kewajiban jangka pendek atau utang yang segera jatuh tempo pada saat ditagih secara keseluruhan. Current Ratio dapat dirumuskan sebagai berikut:

$\mathrm{CR}=$ Aktiva Lancar / Kewajiban lancar

\section{b. Debt to Equity Ratio}

Menurut Kasmir (2015), Debt to Equity Ratio (DER) berguna untuk mengetahui jumlah dana yang disediakan pinjaman (kreditor) dengan pemilik perusahaan. Debt to Equity Ratio (DER) merupakan rasio yang digunakan untuk menunjukkan kemampuan modal sendiri perusahaan untuk memenuhi kewajibannya. Debt to Equity Ratio dapat dirumuskan sebagai berikut: 
DER $=$ Total Hutang $/$ Total Modal

\section{c. Return on Equity}

Menurut Harahap (2009), Return On Equity adalah rasio yang menunjukkan berapa persen diperoleh laba bersih bila diukur dari modal pemilik, semakin besar semakin bagus". Return On Equity dapat dirumuskan sebagai berikut:

$\mathrm{ROE}=$ Laba bersih sesudah pajak / Modal perusahaan x $100 \%$

\section{Teknik Analisis Data}

1. Statistik Deskriptif

Menurut Sugiyono (2012), statistik deskriptif adalah statistik yang digunakan untuk menganalisa data dengan cara mendeskripsikan atau menggambarkan data yang telah terkumpul sebagaimana adanya tanpa bermaksud membuat kesimpulan yang berlaku untuk umum. Alat analisis yang digunakan adalah Eviews 9.

2. Uji Asumsi Klasik

a. Uji Normalitas

Uji normalitas bertujuan untuk menguji apakah dalam suatu model regresi linier variabel terikat dan variabel bebas keduanya mempunyai distribusi normal atau tidak. Menurut Ghozali (2011) Uji normalitas bertujuan untuk menguji apakah dalam model regresi variabel pengganggu atau residual memiliki distribusi normal. Cara untuk melihat normalitas adalah dengan menggunakan uji Jarque-Bera. Pengambilan keputusan uji normal dengan cara, jika nilai probabilitas JB lebih besar dari 0,05 (prob. J-B > $0,05)$ maka berdistribusi normal. Jika nilai probabilitas J-B lebih kecil dari 0,05 (prob. J-B $<0,05$ ) maka berdistribusi tidak normal. b. Uji Autokorelasi

Uji autokorelasi bertujuan untuk mengetahui apakah dalam suatu model regresi linier terdapat korelasi antara pengganggu pada periode $\mathrm{t}$ dengan kesalahan pada periode t-1 (sebelumnya). Model regresi yang baik adalah regresi yang bebas dari autokorelasi (Ghozali, 2011). Alat analisis yang digunakan adalah uji Durbin Watson. Untuk mengetahui terjadi atau tidak autokorelasi dilakukan dengan membandingkan nilai statistik hitung Durbin Watson pada perhitungan regresi dengan statistik tabel Durbin Watson pada tabel. Dasar pengambilan keputusan adalah sebagai berikut :

a. Jika 4 - DL $<$ DW < 4, maka terjadi autokorelasi negatif

b. Jika $4-$ DU $<$ DW $<4-$ DL, maka tidak ada kesimpulan

c. Jika DU < DW < $4-$ DU, maka tidak terjadi autokorelasi

d. Jika DL < DW < DU, maka tidak ada kesimpulan

e. Jika $0<\mathrm{DW}<\mathrm{DL}$, maka terjadi autokorelasi positif

Keterangan : DL = batas bawah DW, $\mathrm{DU}=$ batas atas DW

c. Uji Heteroskedastisitas

Uji heteroskedastisitas ini bertujuan untuk menguji apakah dalam model regresi terjadi ketidaksamaan varians dari residual satu pengamatan ke pengamatan lain. Pengujian heterokedastisitas dapat dilakukan dengan Uji White. Uji White dilakukan dengan meregresikan residual kuadrat sebagai variabel dependen dengan variabel dependen ditambah dengan 
kuadrat variabel independen, kemudian ditambahkan lagi dengan perkalian dua variabel independen. Jika Prob. Chi square (p-value) > $0,05 \quad \rightarrow \quad$ tidak terjadi heteroskedastisitas. Begitupun sebaliknya jika Prob. Chi square (p-value) $<0,05 \rightarrow$ terjadi heteroskedastisitas (Kusuma, 2012).

d. Uji Multikolinieritas

Uji multikolinieritas dideteksikan dengan cara menguji korelasi antar variabel independennya dan pengujian regresi auxiliary (meregresikan salah satu independen dengan variabel independennya). Pada pengujian variabel korelasi bisa dikatakan saling berkorelasi jika nilai korelasi (derajat kepercayaan) lebih besar dari 90\% ( > 0,90), maka akan menunjukkan adanya gejala multikolinieritas. Jika nilai korelasi (derajat kepercayaan) lebih kecil dari $90 \%(<0,90)$, maka akan menunjukkan tidak adanya gejala multikolinieritas.

Pada pengujian auxiliary dikatakan jika nilai uji probabilitas dari $\mathrm{F}$ statistik lebih kecil dari 5\% (p-value $\mathrm{F}<0,05$ ), pada semua pengujian regres variabel independen, maka mengidentifikasikan adanya pengaru hubungan yangkuat antarvariabel independen secara bersama dan adanya masalah multikolinieritas antar variabel independen. Begitupun sebaliknya jika nilai uji probabilitas dari $\mathrm{F}$ statistic lebih besar dari 5\% (pvalue $\mathrm{F}>0,05)$ pada semua pengujian regresi variabel independen, maka mengidentifikasikan tidak adanya pengaruh hubungan yang kuat antarvariabel independen secara bersama dan tidak adanya masalah multikolinieritas (Kusuma, 2012).

\section{Analisis Regresi Data Panel}

Regresi data panel ini digunakan untuk menguji Current Ratio, Debt to Equity Ratio dan Return on Equity Terhadap terhadap Return Saham. Adapun persamaan regresi yaitu sebagai berikut:

Yit $=\alpha+\beta 1$ CRit $+\beta 2$ DERit $+\beta 3$ ROEit

Keterangan:

$\begin{array}{ll}\text { Yit } & =\text { variabel Return Saham } \\ \mathrm{A} & =\text { Intercept } / \text { Konstanta } \\ \beta 1, \beta 2, \beta 3 & =\text { Koefisien } \\ \text { Crit } & =\text { Current Ratio } \\ \text { DERit } & =\text { Debt to Equity Ratio } \\ \text { ROEit } & =\text { Return On Equity }\end{array}$

a. Uji Chow

Langkah awal dalam penentuan model adalah dengan meregresikan data dengan fixed effect, kemudian dilakukan dengan uji Chow dengan cara membandingkan nilai prob. Chi square dengan 0,05. Model common effect akan digunakan jika nilai prob. Chi square > 0,05 dan sebaliknya jika nilai prob. Chi square $<0,05$, maka fixed effect yang dipilih. Langkah selanjutnya jika model yang digunakan adalah common effect maka penentuan model berhenti disini, dengan kata lain model yang lebih tepat digunakan adalah model common effect (Kusuma, 2012). Namun jika uji Chow menunjukkan bahwa fixed effect yang dipilih, maka akan dilanjutkan pengujian yang kedua (uji Hausman) yaitu 
dengan membandingkannya dengan model random effect.

b. Uji Hausman

Uji Hausman yaitu untuk memilih apakah menggunakan model Fixed Effect atau Random Effect. Model random effect akan digunakan jika nilai prob. Cross section random > 0,05 dan sebaliknya jika prob.cross section random $<0,05$ maka fixed effect yang dipilih menjadi model regresi panelnya.

\section{Uji Parsial (Uji T)}

Menurut Ghozali (2011), uji stastistik t pada dasarnya menunjukkan seberapa jauh pengaruh satu variabel independen secara individual dalam menerangkan variabel dependen. Pengujian dilakukan dengan menggunakan tingkat signifikansi 0,05 $(\alpha=5 \%)$. Jika nilai probabilitas > tingkat signifikansi $(0,05)$, maka hipotesis yang diajukan ditolak. Jika nilai probabilitas < tingkat signifikansi $(0,05)$, maka hipotesis yang diajukan diterima.

5. Uji Koefisien Determinasi

Koefisien determinasi pada intinya mengukur seberapa jauh kemampuan model dalam menerangkan variasi variabel dependen. Nilai koefisien determinasi adalah antara nol dan satu. Nilai koefisien yang kecil berarti kemampuan variabel-variabel independen dalam menjelaskan variasi variabel dependen amat terbatas. Nilai yang mendekati satu berarti variabelvariabel independen memberikan hampir semua informasi yang dibutuhkan untuk memprediksi variasi

\section{HASIL PENELITIAN DAN PEMBAHASAN}

\section{Hasil Penelitian}

1. Hasil Analisis Statistik Deskriptif

Statistik Deskriptif

\begin{tabular}{|l|c|c|c|c|}
\hline & CR & DER & ROE & RS \\
\hline Mean & 324,2995 & 5,113681 & 136,5983 & 20,39607 \\
\hline Median & 180,0850 & 0,650000 & 8,215000 & 0,000000 \\
\hline Maximum & 3105,960 & 624,9600 & 18370,99 & 810,0599 \\
\hline Minimum & 19,39000 & 0,030000 & $-15,22000$ & $-0,998879$ \\
\hline Std. Dev. & 428,4462 & 52,01821 & 1530,190 & 121,1201 \\
\hline Observations & 144 & 144 & 144 & 144 \\
\hline
\end{tabular}

Dari hasil analisis statistik deskriptif, diperoleh informasi bahwa jumlah observasi penelitian berjumlah 144. Nilai mean pada variable CR adalah 324,2995, median sebesar 180,0850, nilai tertinggi 3105,960 dan nila terendah 19,39000 . Artinya nilai CR terbesar yang dimiliki perusahaan sampel selama periode penelitian adalah sebesar 3105,960 yaitu dimiliki oleh Laguna Cipta Griya Tbk. pada tahun 2017, sedangkan nilai CR terendah perusahaan sampel selama periode penelitian adalah sebesar 19,39000 yang dimiliki oleh Bekasi Asri Pemula Tbk. pada tahun 2015.

Variabel DER memiliki mean 5,113681, median 0,650000, nilai tertinggi 624,9600, nilai terendah 0,030000. Artinya nilai DER terbesar yang dimiliki perusahaan sampel selama periode penelitian adalah sebesar 624,9600 yaitu dimiliki oleh Metropolitan Land Tbk. pada tahun 2017, sedangkan nilai DER terendah perusahaan sampel selama periode penelitian adalah sebesar 0,030000 yaitu dimiliki Laguna Cipta Griya Tbk. pada tahun 2017, dan Rista Bintang Mahkota Sejati Tbk. pada tahun 2016. 
Variabel ROE memiliki mean 136,5983, median 8,215000, nilai tertinggi 18370,99 , dan nilai terendah -15.22000 . Artinya nilai ROE terbesar yang dimiliki perusahaan sampel selama periode penelitian adalah sebesar 18370,99 yaitu dimiliki oleh Metropolitan Land Tbk. pada tahun 2017, sedangkan nilai ROE terendah perusahaan sampel selama periode penelitian adalah sebesar $-15,22000$ yaitu dimiliki oleh Cowell Depelopment Tbk. pada tahun 2015.

Variabel return saham memiliki mean 20,39607, median 0,000000, nilai tertinggi 810,0599, dan nilai terendah 0.998879 . Artinya nilai return terbesar yang dimiliki perusahaan sampel selama periode penelitian adalah sebesar 810,0599 yaitu dimiliki oleh Cowell Depelopment Tbk. pada tahun 2017, sedangkan nilai return terendah perusahaan sampel selama periode penelitian adalah sebesar $-0,998879$ yaitu dimiliki oleh Lippo Karawaci Tbk. pada tahun 2014.

2. Hasil Uji Asumsi Klasik

a. Uji Normalitas

\section{Hasil Uji Normalitas}

\begin{tabular}{|c|c|}
\hline Jarque-Bera & Probability \\
\hline 4710,922 & 0,000000 \\
\hline
\end{tabular}

Hasil uji normalitas pada tabel di atas, nilai residual dalam model regresi tidak berdistribusi normal. Hal ini ditunjukkan pada nilai prob. J-B sebesar 0,000000 , yang mana lebih kecil dari $\alpha 5 \%$ $(0,000000<0,05)$. Untuk mengatasi masalah ini yaitu dengan menggunakan scatter plot pada excel dan menghilangkan data yang outlayer.

\section{Hasil Uji Normalitas}

\begin{tabular}{|c|c|}
\hline Jarque-Bera & Probability \\
\hline 4,703443 & 0,095205 \\
\hline
\end{tabular}

Berdasarkan hasil uji normalitas menggunakan uji Jarque Bera dilakukan perbaikan pada tabel di atas, menunjukkan bahwa residual persamaan regresi pada uji normalitas tersebut berdistribusi normal. Hal ini ditunjukkan pada nilai prob. J-B sebesar 0,095205, yang mana lebih besar dari 5\% $(0,095205>0,05)$.

b. Uji Autokorelasi

Hasil Uji Autokorelasi

\begin{tabular}{|l|l}
\hline Durbin-Watson Stat & 1,983368
\end{tabular}

Hasil uji korelasi terlihat pada tabel di atas bahwa nilai Durbin Watson stat adalah $1,983368, \mathrm{DL}=$ 1,6854, $\mathrm{DU}=1,7704$. Dengan demikian dapat disimpulkan bahwa $1,7704<1,983368<4-1,7704$ yaitu tidak mempunyai autokorelasi.

c. Uji Heteroskedastisitas Hasil Uji Heteroskedastisitas

\begin{tabular}{|c|c|c|c|}
\hline $\begin{array}{c}\text { Obs*R- } \\
\text { squared }\end{array}$ & 14,90119 & $\begin{array}{c}\text { Prob.Chi- } \\
\text { Square(9) }\end{array}$ & 0,0937 \\
\hline
\end{tabular}

Dari hasil pemeriksaan terhadap gejala heteroskedastisitas dengan uji White pada tabel di atas menunjukkan masing-masing nilai probabilitas Chi-Square pada Obs*R squared 0,0937>0,05. Maka uji heteroskedastisitas pada residual masing-masing regresi menunjukkan tidak terjadi heteroskedastisitas pada model regresi dengan variabel dependen CR, DER, dan ROE terhadap variabel independen return saham. 
d. Uji Multikolinieritas

Multikolinieritas

\begin{tabular}{|c|c|c|c|}
\hline & CR & DER & ROE \\
\hline CR & 1,000000 & $-0,357545$ & $-0,318051$ \\
\hline DER & $-0,357545$ & 1,000000 & 0,274640 \\
\hline ROE & $-0,318051$ & 0,274640 & 1,000000 \\
\hline
\end{tabular}

Uji multikolinieritas yang dilakukan menggunakan metode korelasi antar variable independen yaitu CR, DER dan ROE. Terlihat pada tabel di atas, nilai korelasi antar variable independen CR, DER, dan $\mathrm{ROE}<90 \%$ atau 0,90, maka menunjukkan tidak adanya gejala multikolinieritas.

3. Hasil Analisis Regresi Data Panel a. Hasil Uji Chow

\section{Hasil Ujichow}

\begin{tabular}{|c|c|c|c|}
\hline Effects Test & \multicolumn{1}{c|}{ Statistic } & \multicolumn{1}{c|}{ d.f. } & Prob. \\
\hline Cross-section Chi-square & 27,969917 & 35 & 0,7947 \\
\hline
\end{tabular}

Dari hasil regresi data panel di atas terlihat bahwa nilai probabilitas chi square sebesar $0,7947>0,05$, maka hasil ini menyimpulkan bahwa model common effect yang digunakan dalam analisis regresi data panel.

b. Persamaan Regresi

Dari hasil regresi data panel, diperoleh persamaan regresi sebagai berikut:

$\mathrm{Y}=\alpha+\beta 1 \mathrm{CR}+\beta 2 \mathrm{DER}+\beta 3 \mathrm{ROE}$

$\mathrm{Y}=-0,009689+0,0000403 \mathrm{CR}-$ $0,157973 \mathrm{DER}+0,015935 \mathrm{ROE}$

Nilai konstanta $(\alpha)$ sebesar 0,009689 menunjukkan bahwa apabila variabel CR, DER dan ROE konstan, maka nilai variabel retur saham sebesar -0,009689.
Besarnya nilai koefisien regresi $(\beta 1)$ sebesar 0,0000403 nilai $\beta 1$ yang positif menunjukkan adanya hubungan yang searah antara variabel return saham dengan $\mathrm{CR}$ yang artinya jika nilai variabel $\mathrm{CR}$ naik sebesar 1 maka nilai return saham akan naik sebesar 0,0000403, jika nilai variabel CR turun sebesar 1 maka nilai return saham akan turun sebesar $-0,0000403$. Dengan asumsi variabel bebas lainnya tidak konstan.

Besarnya nilai koefisien regresi $(\beta 2)$ sebesar $-0,157973$ nilai $\beta 2$ yang negatif menunjukkan adanya hubungan yang berlawanan arah antara variabel return saham dengan DER yang artinya jika nilai variabel DER naik sebesar 1 maka nilai return saham akan turun sebesar $-0,157973$, jika nilai variabel DER turun sebesar 1 maka nilai return saham akan naik sebesar 0,157973. Dengan asumsi variabel bebas lainnya tidak konstan.

Besarnya nilai koefisien regresi ( $\beta 3$ ) sebesar 0,015935 nilai $\beta 3$ yang positif menunjukkan adanya hubungan yang searah antara variabel return saham dengan ROE yang artinya jika nilai variabel ROE naik sebesar 1 maka nilai return saham akan naik sebesar 0,015935, jika nilai variabel ROE turun sebesar 1 maka nilai return saham akan turun sebesar 0,015935. Dengan asumsi variabel bebas lainnya tidak konstan.

\section{Hasil Uji Parsial (Uji T)}

Nilai prob CR sebesar 0,7078 , koefisien regresi sebesar 0,0000403, hasilnya menyatakan bahwa CR berpengaruh positif tidak signifikan terhadap return saham. Hasil analisis ini menunjukkan bahwa hipotesis 
pertama yang diujikan dalam penelitian ini ditolak, yang menyatakan bahwa CR berpengaruh positif tidak signifikan terhadap return saham.

Nilai prob DER sebesar 0,0278, koefisien regresi sebesar $-0,157973$, hasilnya menyatakan bahwa DER berpengaruh negatif signifikan terhadap return saham. Hasil analisis ini menunjukkan bahwa hipotesis kedua yang diujikan dalam penelitian ini diterima,yang menyatakan bahwa DER berpengaruh negatif signifikan terhadap return saham.

Nilai prob ROE sebesar 0,0004, koefisien regresi sebesar 0,015935, hasilnya menyatakan bahwa ROE berpengaruh positif signifikan terhadap return saham. Hasil analisis ini menunjukkan bahwa hipotesis ketiga yang diujikan dalam penelitian ini diterima, yang menyatakan bahwa ROE berpengaruh positif signifikan terhadap return saham.

\section{Hasil Uji Koefisien Determinasi}

Berdasarkan hasil uji, dapat dilihat nilai koefisien determinasi (R2) sebesar 0,110187 atau $11,01 \%$. Hasil tersebut menunjukkan bahwa CR, DER, dan ROE mampu menjelaskan return saham sebesar $11,01 \%$, sedangkan sisanya sebesar $88,99 \%$ dijelaskan oleh variabel lain yang tidak ada dalam penelitian ini.

\section{Pembahasan}

1. Pembuktian Hipotesis Pertama

Hipotesis 1 menduga bahwa variabel Current Ratio (CR) berpengaruh positif signifikan terhadap return saham, sedangkan hasil penelitian menunjukkan bahwa Current Ratio (CR) berpengaruh positif tidak signifikan terhadap return saham, sehingga hipotesis 1 tidak terdukung. Hal ini menunjukkan bahwa return saham yang tinggi pada perusahaan Real Estate dan Property yang terdaftar di BEI periode tahun 2014-2017 tidak dipengaruhi oleh besarnya nilai Current Ratio (CR).

Hasil penelitian ini sejalan dengan Erari (2014) yang menyatakan bahwa Current Ratio (CR) berpengaruh positif tidak signifikan terhadap return saham. Current Ratio (CR) yang rendah biasanya dianggap menunjukkan terjadinya masalah dalam likuiditas dan merupakan indikator awal mengenai ketidakmampuan perusahaan untuk memenuhi kewajiban jangka pendeknya. CR yang tinggi, yang berarti likuiditas yang tinggi juga menunjukkan bahwa perusahaan kurang mampu mengelola money to create money, yang pada akhirnya dapat mengurangi kemampuan laba perusahaan. Dari pengukuran rasio, apabila rasio lancar rendah, dapat dikatakan bahwa perusahaan kurang modal untuk membayar utang dan apabila hasil pengukuran rasio tinggi, belum tentu kondisi perusahaan sedang baik (Kasmir, 2008).

2. Pembuktian Hipotesis Kedua

Hipotesis 2 menduga bahwa variabel Debt to Equity Ratio (DER) berpengaruh negatif signifikan terhadap return saham. Hasil penelitian menunjukkan bahwa variabel Debt to Equity Ratio (DER) berpengaruh negatif signifikan terhadap return saham sehingga hipotesis 2 didukung. Hal ini menunjukkan bahwa return saham yang tinggi pada perusahaan Real Estate dan Property yang terdaftar di BEI periode tahun 20142017 dipengaruhi oleh besarnya nilai Debt to Equity Ratio (DER) yang semakin rendah. 
Dengan demikian, penelitian ini sejalan yang dilakukan oleh Verawati (2014) yang menyatakan bahwa Debt to Equity Ratio (DER) berpengaruh negatif signifikan terhadap return saham. Semakin tinggi DER menunjukkan komposisi hutang semakin besar dibandingkan dengan total modal sendiri, hal ini menunjukkan sumber modal perusahaan tergantung dari pihak luar, sehingga akan mengurangi minat investor untuk menanamkan modalnya diperusahaan yang memiliki DER tinggi. Menurunnya minat investor berdampak pada penurunan harga saham yang berakibat terhadap menurunnya total return perusahaan Real Estate dan Property di BEI. Tingginya tingkat ketergantungan perusahaan real estate dan property terhadap utang dalam proses bisnisnya tentu akan mengakibatkan tingkat risiko yang diterima investor yang berinvestasi pada saham perusahaan real estate dan property juga akan tinggi. Hal ini tentu akan mengurangi minat investor untuk berinvestasi pada saham perusahaan tersebut, berdasarkan hasil penelitian ini dapat dikatakan bahwa fluktuasi DER akan memberi pengaruh yang signifikan terhadap return saham.

\section{Pembuktian Hipotesis Ketiga}

Hipotesis 3 menduga bahwa variabel Return On Equity (ROE) berpengaruh positif signifikan terhadap return saham. Hasil penelitian menunjukkan bahwa variabel Return On Equity (ROE) berpengaruh positif signifikan terhadap return saham sehingga hipotesis 3 di dukung. Hal ini menunjukkan bahwa return saham yang tinggi pada perusahaan Real Estate dan Property yang terdaftar di BEI periode tahun 2014-2017 dipengaruhi oleh besarnya nilai Return On Equity (ROE) yang semakin tinggi.

Dengan demikian, penelitian ini sejalan yang dilakukan oleh Yunita (2013) yang menyatakan bahwa ROE terbukti berpengaruh positif dan signifikan terhadap return saham. Semakin tinggi ROE menunjukkan semakin efisien perusahaan dalam menggunakan modal para pemegang saham untuk menghasilkan keuntungan atau laba bersih. ROE memiliki hubungan yang positif dengan return saham, semakin besar nilai ROE maka akan menyebabkan harga saham menjadi meningkat. Semakin tinggi ROE berarti semakin baik kinerja perusahaan dalam mengelola modalnya untuk menghasilkan laba bersih atau keuntungan untuk pemegang saham.

\section{KESIMPULAN DAN SARAN}

\section{Kesimpulan}

1. Current Ratio (CR) berpengaruh positif tidak signifikan terhadap return saham pada perusahaan Real Estate dan Property di Bursa Efek Indonesia periode tahun 2014 - 2017.

2. Debt to Equity Ratio (DER) berpengaruh negatif signifikan terhadap return saham pada perusahaan Real Estate dan Property di Bursa Efek Indonesia periode tahun 2014 - 2017.

3. Return On Equity (ROE) berpengaruh positif signifikan terhadap return saham pada perusahaan Real Estate dan Property di Bursa Efek Indonesia periode tahun $2014-2017$.

\section{Saran}

1. Untuk akademisi/ilmu pengetahuan, disarankan untuk menambah variabel independen lainnya yang memungkinkan akan berpengaruh meningkatkan return saham, misalnya 
TATO, EPS, PER, EPS dan juga menambah tahun penelitian agar hasil penelitian lebih baik.

2. Bagi Investor untuk memperhatikan modal dan laba agar di masa yang akan datang investor dapat memperoleh keuntungan dan meningkatkan return saham.

3. Bagi Perusahaan disarankan untuk memperhatikan profitabilitas dalam membuat keputusan investasi agar dapat memberikan reaksi di pasar yang akan berdampak pada peningkatan harga saham, jika harga saham naik maka return saham juga akan meningkat, sehingga dapat meningkatkan minat investor untuk berinvestasi terhadap perusahaan.

\section{DAFTAR PUSTAKA}

Erari, Anita. (2014). Analisis Pengaruh Current Ratio, Debt To Equity, dan Return On Asset Terhadap Return Saham Pada Perusahaan Pertambangan di Bursa Efek Indonesia. Jurnal Fakultas Ekonomi Manajemen. Vol.5 No.2 September 2014.

Ghozali, Imam. (2011). Aplikasi Analisis Multivariate Dengan Program IBM SPSS 19. Semarang: Badan Penerbit Universitas Diponegoro.

Halim, Abdul. (2005). Analisis Investasi. Edisi Dua. Jakarta: Salemba Empat.

Hanafi, Mamduh M. dan Abdul Halim. (2012). Analisis Laporan Keuangan. Yogyakarta: UPP STIM YKPN.

Harahap, Sofyan Syafri. (2009). Analisis Kritis Atas Laporan Keuangan. Jakarta: PT Raja Grafindo Persada.

Hartono, Jogiyanto. (2007). Teori Portofolio dan Analisis Investasi. Edisi 5. Yogyakarta: BFFE.

Hartono, Jogiyanto. (2008). Teori Portofolio dan Analisis Investasi. Edisi Kelima. Yogyakarta: BPFE.
Hartono, Jogiyanto. (2010). Teori Portofolio dan Analisis Investasi. Yogyakarta: BPFE.

https://www.sahamok.com/beda-realestate-dengan-property/. Diakses pada tanggal 1 Oktober 2018 pukul 16.15 WIB.

https://properti.kompas.com/read/2018/04/ 02/153000621/pengembang-properti-bisajadi-acuanpertumbuhan-ekonomi. Diakses tanggal 1 Oktober 2018 padapukul 13.30 WIB.

Kasmir. (2008). Analisis Laporan Keuangan. Edisi Pertama. Jakarta: PT Raja Grafindo Persada.

Kasmir. (2013). Analisis Laporan Keuangan. Jakarta: PT Raja Grafindo Persada.

Kasmir. (2015). Pengantar Manajemen Keuangan. Edisi Kedua. Jakarta: Prenada Media Group.

Kurnia, Nike. (2013). Pengaruh Kinerja Perusahaan Dan Risiko Sistematis Terhadap Return Saham (Studi Empiris pada Perusahaan Property dan Real Estate yang Terdaftar di BEI). Skripsi. Sumatra Barat: Universitas Negeri Padang.

Kusuma, Desta Rizky dan Deny Ismanto. (2012). Petunjuk Praktikum EVIEWS 6. Yogyakarta: Universitas Ahmad Dahlan.

Laksono, Dwi Cahyo. (2017). Pengaruh Rasio Keuangan Terhadap Return Saham Pada Perusahaan Manufaktur Yang Terdaftar Di Bursa Efek Indonesia. Skripsi. Yogyakarta: Universitas Negeri Yogyakarta.

Munawir. (2014). Analisis Laporan Keuangan. Yogyakarta: Liberty Yogyakarta

Prihantini, Ratna. (2009). Pengaruh Inflasi, Nilai Tukar, ROA, DER dan CR terhadap Return Saham industry real estate and property yang listed di Bursa Efek Indonesia periode 2003-2006. Tesis. Semarang: Universitas Diponegoro. 
Ratna, Fransiska Rr. (2009). Analisis Pengaruh Rasio Likuiditas, Aktivitas, Leverage dan Profitabilitas Terhadap Return Saham Pada Perusahaan Manufaktur yang Terdaftar di BEI Periode Tahun 2005 - 2007. Skripsi. Yogyakarta: Universitas Sanata Dharma.

Sugiyono. (2012). Metode Penelitian Kuantitatif Kualitatif dan $R \& D$. Bandung: Alfabeta.

Tandellin E. (2010). Analisis Investasi dan Mnajemen Fortofolio. Edisi pertama Cetakan pertama. Yogyakarta: BPFE.

Verawati, Rika. (2014). Faktor-Faktor Penentu Yang Mempengaruhi Return Saham Perusahaan Manufaktur Yang Terdaftar Di Bursa Efek Indonesia (BEI) Periode 2008-2013. Skripsi. Yogyakarta: Universitas Negeri Yogyakarta.

www.yahoofinance.com. Diakses pada tanggal 15 Februari 2019 pada pukul 14.00 WIB

www.idx.co.id. Diakses pada tanggal 16 Januari 2019 pada pukul 10.00 WIB

Yunita, Nova. (2013). Analisis Pengaruh Rasio Profitabilitas Dan Rasio Solvabilitas Terhadap Return Saham Perusahaan Manufaktur Yang Terdaftar Di BEI Periode 2008-2010. Jurnal Manajemen. 